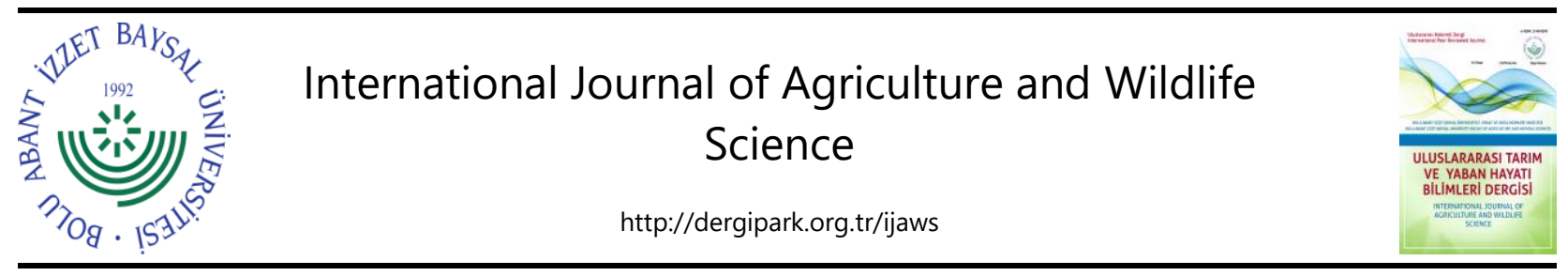

Research Article

\title{
Effects of Environmental Variations on Yield of Oriental Tobaccos ${ }^{* *}$
}

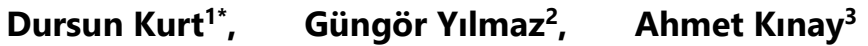 \\ ${ }^{1}$ Ondokuz Mayıs University, Bafra Vocational School, Department of Plant and Animal Production, Samsun, Turkey \\ ${ }^{2}$ Yozgat Bozok University, Faculty of Agriculture, Department of Field Crops, Yozgat, Turkey \\ ${ }^{3}$ Tokat Gaziosmanpasa University, Faculty of Agriculture, Department of Field Crops, Tokat, Turkey
}

Received: 26.01.2020 Accepted: 29.05.2020

\begin{abstract}
Keywords:
Basma tobacco, genotype $x$ environment, morphological characteristics, Nicotiana tabacum L.
\end{abstract}

\section{*Corresponding author} dursun.kurt@omu.edu.tr

\begin{abstract}
The study was conducted to determine the impacts of environmental variations on yield and yield related properties of tobacco. The experimental layout was in the randomized blocks with three replicates in four different locations (Erbaa-Evciler, Erbaa-Karayaka, Gümüşhacıköy, Bafra) using 21 lines and four standard varieties that stand out with their different characteristics. The variation in plant height, number of leaves, leaf width, leaf length and leaf yield of genotypes were investigated at different ecologies. All the parameters investigated of the genotypes have been significantly affected by changing environmental conditions. Plant height ranged from $49.33 \mathrm{~cm}$ to $177.32 \mathrm{~cm}$, the number of leaves from 21.83 to 47.10 per plant, leaf width from 6.83 to $16.31 \mathrm{~cm}$, leaf length from 13.01 to $28.93 \mathrm{~cm}$, and yield ranged from $79.17 \mathrm{~kg}^{-1}$ to $238.98 \mathrm{~kg} \mathrm{da}^{-1}$. The results for the performances of genotypes in all environments showed that 5 lines (ERB-11, ERB-14, ERB-16, ERB-21, ERB-35) for plant height, 6 lines (ERB-6, ERB-7, ERB-11, ERB-14, ERB-16, ERB-35) for the number of leaves, 10 lines (ERB-9, ERB-16, ERB-17, ERB-18, ERB19, ERB-21, ERB-25, ERB-26, ERB-27, ERB-30) for leaf width, 1 line (ERB-16) in for leaf length and 13 lines (ERB-6, ERB-7, ERB-9, ERB-13, ERB-16, ERB-18, ERB-19, ERB-21, ERB-25, ERB-27, ERB-30, ERB-35, ERB-38) for yield come to the fore.
\end{abstract}

\section{Çevresel Varyasyonların Oryantal Tütünlerin Verimi Üzerine Etkileri}

\section{Anahtar kelimeler:}

Basma tütünü, genotip $x$ çevre, morfolojik karakterler, Nicotiana tabacum L.
Özet. Çalışma tütünün verim ve verim ile ilişkili özelliklerini çevre değişkenliklerinin nasıl etkilediğini belirlemek amacıyla yapılmıştır. Araştırma, farklı özellikleri ile öne çıkan 21 hat ve dört standart çeşit ile dört farklı lokasyonda (Erbaa-Evciler, Erbaa-Karayaka, Gümüşhacıköy, Bafra) tesadüf blokları deneme deseninde üç tekrarlı olarak yürütülmüştür. Farklı genotiplerin bitki boyu, yaprak sayısı, yaprak eni, yaprak boyu ve kuru yaprak verimi karakterlerinin, farklı ekolojilerde ortaya koyduğu varyasyon incelenmiştir. İncelenen parametrelerin tümünde genotiplerin değişen çevre koşullarından önemli derecede etkilendiği belirlenmiştir. Bitki boyu $49.33 \mathrm{~cm}$ ile $177.32 \mathrm{~cm}$, yaprak sayısı 21.8347.10 adet/bitki, yaprak eni $6.83-16.31 \mathrm{~cm}$, yaprak boyu $13.01-28.93 \mathrm{~cm}$ ve verim $79.17 \mathrm{~kg} \mathrm{da}^{-1}$ ile $238.98 \mathrm{~kg} \mathrm{da}^{-1}$ aralığında değişmiştir. Tüm çevrelerde gösterdikleri performansları ile bitki boyu bakımından 5 hat (ERB-11, ERB-14, ERB-16, ERB-21, ERB-35), yaprak sayısı bakımından 6 hat (ERB-6, ERB-7, ERB-11, ERB-14, ERB-16, ERB-35), yaprak eni bakımından 10 hat (ERB-9, ERB-16, ERB-17, ERB18, ERB-19, ERB-21, ERB-25, ERB-26, ERB-27, ERB-30), yaprak boyu bakımından 1 hat (ERB-16) ve verim bakımından 13 hat (ERB-6, ERB-7, ERB-9, ERB-13, ERB-16, ERB-18, ERB-19, ERB-21, ERB-25, ERB-27, ERB-30, ERB-35, ERB-38) öne çıkmıştır.

\footnotetext{
${ }^{* *}$ The article is summarized from the PhD thesis of the corresponding author.

ORCID ID (By author order)

(D) 0000-0001-6697-3954 (1D) 0000-0003-0070-5484 (D) 0000-0003-4554-2148
} 


\section{INTRODUCTION}

High levels of oriental tobacco production and export in Turkey are related to the quality improvement of tobacco grown provided to cigarette blends. Basma-type tobaccos of this group are small-partly mediumsized, leaves are light red and dark yellow tones. The aroma is the most important characteristic of Basma-type tobaccos (Camas et al., 2009a). Although adaptation and breeding studies recently have been conducted on Basma tobacco types in Turkey (Camas et al., 2009b), in general, the effects of cultural practices on leaf yield and quality have been determined (Camas et al., 2009a, 2009b, 2011; Yilmaz and Kinay, 2011; Ozcan, 2014; Kurt and Ayan, 2014; Kinay and Yilmaz, 2016).

Temperature and precipitation are the main factors affecting the growth and development ratio, productivity and chemical composition of the tobacco plants (Dimitrova, 2005). Morphological features of tobacco plants generally depend on the genetic structure of species and characteristics of the climate, while the impact of soil structure is less effective. Tomov (1990) stated that climate conditions significantly affect plant height, whereas the effect on the number of leaves is quite low. The study carried out by KorubinAleksoska (2003) to determine the effect of environmental changes on oriental tobacco revealed that the plant height is the most affected plant characteristic. Sadeghi et al. (2011) investigated the yield performances of 15 hybrid tobacco in eight different environments, and $87.89 \%$ of the variation was attributed to environmental effects, $2.36 \%$ to the genotype and the rest to the genotype $\mathrm{x}$ environment interaction. Color, leaf sizes and smoking characteristics may vary depending on environmental conditions. Leaf form, the color of flowers etc., which do not change depending on external factors, are genetic features and the leaf form is used especially in the type diagnosis (Peksuslu, 1998). Researchers studying in the Marmara (Dolek, 1984) and Black Sea region tobaccos (Karpat, 1989) reported that plant shape, plant height, the number of leaves and leaf sizes have been changed by the year and environment; however, the leaf form was not changed.

Important natural stressors in terms of quality criteria in oriental tobacco are high temperature, water shortage and mineral nutrient deficiency (Senbayram et al., 2005). The presence of heavy metals, excessive salinity, insufficient precipitation, and nitrogen are the important stress factors, and plants suffer yield losses while creating a defense mechanism to overcome the adverse effects of stress (Lambers et al., 2000). The mechanisms developed by plants against these stressors are reducing photosynthesis and leaf area, thickening the leaf, shading the lower leaves by increasing the number of leaves, and narrowing the leaf angle to escape from the sun (Smith et al., 2004). The stress created in different growth periods of the plant by reducing the irrigation water reduced the plant height, the number of leaves and the leaf area during the rapid vegetative growth and product formation periods of tobacco plants (Cakir and Cebi, 2006).

The oriental tobaccos have a very large variation due to the environmental conditions and different cultivation techniques in addition to the inherited structures. The leaf quality is an important attribute of a genotype, which results from the interaction of genotype and environmental conditions, and even the processes from planting until final product in the factory. The quality of a green leaf is a consequence of the common effects of subsequent processes such as curing, ageing and manufacturing processes. Therefore, each of the tobacco type is an ecotype specific to the region where commonly grown. In this study, the variations in characteristics of tobacco lines collected from the regions where Turkey Basma tobacco grown and genetically separated and the effects of different ecologies on these variations have been investigated.

\section{MATERIALS AND METHODS}

\section{Information of Locations}

The research was carried out in four different locations in the Central Black Sea Region where intensive tobacco production takes place. The locations were chosen from tobacco grown areas with different altitudes. Two of the locations were located in Erbaa town, within the borders of Evciler village $\left(40^{\circ} 36^{\prime} 43.48^{\prime \prime} \mathrm{N}\right.$, $\left.36^{\circ} 36^{\prime} 5.25^{\prime \prime} \mathrm{E}\right)$ with an altitude of $581 \mathrm{~m}$ and Karayaka village $\left(40^{\circ} 44^{\prime} 16.45^{\prime \prime} \mathrm{N}, 36^{\circ} 33^{\prime} 58.31^{\prime \prime} \mathrm{E}\right)$ with an altitude of $302 \mathrm{~m}$. The altitudes of Bafra $\left(41^{\circ} 33^{\prime} 45.29^{\prime \prime} \mathrm{N}, 35^{\circ} 52^{\prime} 18.35^{\prime \prime} \mathrm{E}\right)$ and Gümüşhacıköy (4053'1.03"N, $\left.35^{\circ} 12^{\prime} 47.98^{\prime \prime} \mathrm{E}\right)$ experimental fields were $26 \mathrm{~m}$ and $848 \mathrm{~m}$, respectively.

\section{Soil Structure of Locations}

Soil texture in Evciler location was clay loam, while the other three locations had sandy loam texture. Salt content of the soils was quite low, and all experimental fields were slightly alkaline. Soils in Gümüşhacıköy had 
a moderate organic matter content which was the highest organic matter content among four locations. Bafra and Karayaka soils had low and Evciler soil had a very few organic matter. Evciler, Gümüşhacıköy and Bafra soils were moderately calcareous, while Karayaka was calcareous. Soils in all experimental locations were rich in available potassium content. Phosphorus concentrations of Karayaka soil was moderate, while other three locations had a low level of phosphorus (Table 1).

Table 1. Soil analysis results of the locations.

Çizelge 1. Lokasyonların toprak analiz sonuçları.

\begin{tabular}{lcccc}
\hline \multirow{2}{*}{ Properties } & \multicolumn{4}{c}{ Locations } \\
\cline { 2 - 5 } & \multicolumn{1}{c}{ Evciler } & Karayaka & Gümüşhacıköy & Bafra \\
\hline $\mathrm{P}_{2} \mathrm{O}_{5}\left(\mathrm{~kg} \mathrm{da}^{-1}\right)$ & 5.13 Low & 6.18 Modarate & 4.85 Low & $3.45 \mathrm{Low}$ \\
$\mathrm{K}_{2} \mathrm{O}\left(\mathrm{kg} \mathrm{da}^{-1}\right)$ & $169.70 \mathrm{High}$ & 175.30 High & $156.80 \mathrm{High}$ & $137.17 \mathrm{High}$ \\
$\mathrm{Lime}(\%)$ & 10.2 Modarate calca. & 2.39 Calcareous & 5.17 Modarate calca. & $12.73 \mathrm{Modarate}$ calca. \\
Org. Mat. $(\%)$ & 0.95 Very low & 1.43 Low & 2.36 Modarate & 1.76 Low \\
$\mathrm{pH}$ & 7.99 Slightly alkaline & 7.81 Slightly alkaline & 7.98 Slightly alkaline & 7.61 Slightly alkaline \\
$\mathrm{EC}\left(\mathrm{dS} \mathrm{m}^{-1}\right)$ & 0.25 Very low & 0.13 Very low & 1.12 Very low & 0.72 Very low \\
Texture & Clay loam & Sandy loam & Sandy loam & Sandy loam \\
\hline
\end{tabular}

*Soil samples were analyzed in Tokat GOP University, Agriculture Faculty laboratories.

\section{Climatic Data of Locations}

The temperature values, compared to long-term, during the seven-month period including the seedlings, field and curing periods of tobacco were decreased by $25.2 \%$ in Erbaa, $19.3 \%$ in Gümüşhacıköy and $4.1 \%$ increase in Bafra. The temperature decreased in months of April and May in Bafra and in April and October in Gümüşhacıköy, while in Erbaa a colder July and October were experienced compared to previous years (Table 2).

Table 2. Monthly climate datas of the vegetation period of the locations.

Çizelge 2. Lokasyonların vejetasyon dönemine ait aylık iklim verileri.

\begin{tabular}{|c|c|c|c|c|c|c|c|c|c|c|}
\hline \multirow{2}{*}{ Months } & & \multicolumn{3}{|c|}{ Erbaa } & \multicolumn{3}{|c|}{ Gümüşhacıköy } & \multicolumn{3}{|c|}{ Bafra } \\
\hline & & L. Y. & 2017 & D. & L. Y. & 2017 & D. & L. Y. & 2017 & D. \\
\hline & ${ }^{\circ} \mathrm{C}$ & 14.2 & 12.4 & -1.8 & 11.0 & 10.0 & -1.0 & 11.2 & 9.9 & -1.3 \\
\hline \multirow[t]{3}{*}{ April } & $\mathrm{mm}$ & 55.4 & 45.2 & -10.2 & 56.9 & 43.6 & -13.3 & 57.7 & 63.0 & 5.3 \\
\hline & $\%$ & 58.6 & 65.2 & 6.6 & 58.7 & 62.9 & 4.2 & 79.0 & 85.8 & 6.8 \\
\hline & ${ }^{\circ} \mathrm{C}$ & 18.1 & 17.0 & -1.1 & 14.4 & 14.4 & 0 & 15.5 & 15.0 & -0.5 \\
\hline \multirow[t]{3}{*}{ May } & $\mathrm{mm}$ & 62.2 & 50.5 & -11.7 & 75.5 & 70.9 & -4.6 & 47.2 & 53.6 & 6.4 \\
\hline & $\%$ & 60.7 & 71.6 & 10.9 & 59.6 & 69.5 & 9.9 & 79.4 & 87.6 & 8.2 \\
\hline & ${ }^{\circ} \mathrm{C}$ & 21.6 & 21.4 & -0.2 & 18.2 & 18.4 & 0.2 & 20.1 & 20.3 & 0.2 \\
\hline \multirow[t]{3}{*}{ June } & $\mathrm{mm}$ & 48.4 & 94.5 & 46.1 & 74.9 & 87.3 & 12.4 & 34.6 & 45.9 & 11.3 \\
\hline & $\%$ & 58.1 & 73.6 & 15.5 & 58.9 & 79.2 & 20.3 & 74.9 & 84.7 & 9.8 \\
\hline & ${ }^{\circ} \mathrm{C}$ & 23.9 & 20.8 & -3.1 & 20.7 & 21.3 & 0.6 & 22.8 & 23.5 & 0.7 \\
\hline \multirow[t]{3}{*}{ July } & $\mathrm{mm}$ & 24.6 & 1.2 & -23.4 & 26.6 & 8.4 & -18.2 & 31.0 & 0 & -31 \\
\hline & $\%$ & 55.4 & 74.2 & 18.8 & 53.3 & 55.5 & 2.2 & 73.1 & 95.2 & 22.1 \\
\hline & ${ }^{0} \mathrm{C}$ & 23.8 & 25.9 & 2.1 & 21.1 & 22.3 & 1.2 & 22.9 & 24.3 & 1.4 \\
\hline \multirow[t]{3}{*}{ August } & $\mathrm{mm}$ & 9.9 & 1.0 & -8.9 & 11.3 & 9.2 & -2.1 & 47.3 & 24.8 & -22.5 \\
\hline & $\%$ & 55.6 & 65.8 & 10.2 & 50.9 & 67.7 & 16.8 & 74.5 & 75.2 & 0.7 \\
\hline & ${ }^{\circ} \mathrm{C}$ & 20.5 & 22.2 & 1.7 & 17.4 & 20.8 & 3.4 & 19.5 & 21.2 & 1.7 \\
\hline \multirow[t]{3}{*}{ September } & $\mathrm{mm}$ & 16.1 & 2.9 & -13.2 & 13.0 & 13.2 & 0.2 & 59.7 & 13.0 & -46.7 \\
\hline & $\%$ & 57.9 & 61.6 & 3.7 & 53.9 & 51.7 & -2.2 & 76.8 & 75.2 & -1.6 \\
\hline & ${ }^{\circ} \mathrm{C}$ & 15.4 & 13.9 & -1.5 & 12.3 & 12.2 & -0.1 & 15.4 & 15.4 & 0 \\
\hline \multirow[t]{2}{*}{ October } & $\mathrm{mm}$ & 41.7 & 26.9 & -14.8 & 45.4 & 23.9 & -21.5 & 96.8 & 21.8 & -75 \\
\hline & $\%$ & 63.2 & 77.0 & 13.8 & 61.4 & 64.5 & 3.1 & 78.7 & 72.0 & -6.7 \\
\hline
\end{tabular}

L. Y.; Long years (1963-2016), D.; The difference between 2017 and 1963-2016 years; ${ }^{\circ} \mathrm{C}$; Temperature, mm; Precipitation, \%; Relative humidity 
The relative humidity, compared to long term averages was increased in Gümüşhacıköy except for September and in Bafra except for September and October. The average relative humidity in the seven-month period, compared to long term was increased by $19.4 \%$ in Erbaa, $13.7 \%$ in Gümüşhacıköy and $7.5 \%$ in Bafra town. Bafra location is located on the coastline of Black Sea region; therefore, the location draws attention due to the high relative humidity values compared to other locations (Table 2 ).

The precipitation in Erbaa decreased by $18.4 \%$ ( $45.2 \mathrm{~mm}$ ) in the seedling period compared to the long-term average and the producers completed their planting operations in May. Erbaa region received about twice as much $(95.2 \%)$ rainfall $(94.5 \mathrm{~mm})$ in June compared to the long-term, while the precipitation significantly reduced $(1.2 \mathrm{~mm})$ in July. The precipitation in Gümüşhacıköy during seedling period lower compared to the long-term, whereas the precipitation in June $(87.3 \mathrm{~mm}$ ) was increased by $16.5 \%$, which partially delayed the planting in the region. Then, a period of low rainfall was started as in Erbaa location. In contrast to the other three locations, a different production process from the long-term has been experienced in Bafra. The precipitation increased by $9.2 \%$ in April and $13.5 \%$ in May, which led to fast seedling development and the appearance of the diseases. The planting of seedling was delayed in the region due to the $24.6 \%$ excess precipitation $(45.9 \mathrm{~mm})$ experienced in June. The producers, who had problems especially in the preparation of the field due to the increasing rainfall were able to complete the planting process only in the second week of July. Precipitation did not occur in July at Bafra, and the rainfall during the following months was lower compared to the long-term averages (Table 2).

\section{Material}

The material of the study composed of 25 tobacco genotypes including 21 Basma tobacco lines identified as Basma type in Turkey and four standard tobacco varieties/lines (Kurt, 2019).

\section{Methods}

Seedlings of the genotypes were grown in a float system with peat medium within foam viols. Fertilizer containing $6 \mathrm{~kg} \mathrm{da}^{-1} \mathrm{~N}, 4 \mathrm{~kg} \mathrm{da}^{-1} \mathrm{P}_{2} \mathrm{O}_{5}$ and $6 \mathrm{~kg} \mathrm{da}^{-1} \mathrm{~K}_{2} \mathrm{O}$ was applied to the fields before planting the seedlings (Yilmaz and Kinay, 2011). The experimental layout was a randomized block design with three replications. The seedlings were planted with a $45 \mathrm{~cm}$ inter-row and $12 \mathrm{~cm}$ intra-row spacings on $5 \mathrm{~m}$ long plots. The distance between the blocks was $1 \mathrm{~m}$ and two rows of each plots were planted as edge effects. The seedling planting was performed on May 21, 2017 in Evciler, May 19, 2017 in Karayaka, July 4, 2017 in Bafra and June 29, 2017 in Gümüşhacıköy.

The harvest of matured leaves was completed in 3 different priming periods, and each harvest at the locations was completed in one day. The curing was carried out by the sun-cured method, and the leaves lined up on the strings were hung after a day or two with no shade in direct sunlight. The cured tobacco has been clustered and placed in a closed room. The morphological observations were recorded and all the leaves harvested from the net plot area were weighed for yield, and their moisture content was fixed to $17 \%$ and their yield per decare was calculated in $\mathrm{kg}$.

The data obtained in the locations were not homogeneous; therefore, the locations were subjected to variance analysis separately using the SAS software. Duncan's multiple comparison test was used to compare the parameters obtained in different locations and graphed with GraphPad Prism 8 program.

\section{RESULT AND DISCUSSION}

\section{Plant Height (cm)}

The difference in location had a significant $(p<0.01)$ effect on the plant heights of tobacco lines and varieties. Plant height of Basma tobacco was reported between 67 and $119 \mathrm{~cm}$ (Camas et al., 2009b) and 125.1 to $137.1 \mathrm{~cm}$ (Yilmaz and Kinay, 2011). The plant height of Xanthi 2A variety ranged from 136 to $159 \mathrm{~cm}$ in Bafra (Kurt and Ayan, 2014) and from 73.1 to $81.9 \mathrm{~cm}$ in Erbaa (Kınay and Yılmaz, 2016). The length of Xanthi 81 varieties in Erbaa ecological conditions was between 85 and $89 \mathrm{~cm}$ (Ozcan, 2014). The studies conducted on Basma type tobacco (Peksuslu, 1998; Camas, 1998; Camas et al., 2011; ATEA, 2012) revealed that the length of plant height can be considered as the moderate-tall group.

The plant height of tobacco has a strong and positive relationship with the number of leaves and the yield (Aytac, 2016). Tomov (2005) reported that climatic conditions have a significant impact on plant height of tobacco, and similarly, Korubin-Aleksoska (2003) indicates that plant height is the most affected characteristic 
of oriental tobacco under varying environmental conditions. The results related to variability in the averages of genotype and location confirm this finding. The plant height at four locations varied from $49.33 \mathrm{~cm}$ to 177.32 $\mathrm{cm}$, which indicates a high range of variability. The highest mean plant height was obtained in Gümüşhacıköy location $(145.15 \mathrm{~cm})$ that was $133.55 \%(62.15 \mathrm{~cm}), 21.55 \%(119.42 \mathrm{~cm})$ and $14.91 \%(126.32 \mathrm{~cm})$ higher than the plant height obtained in Evciler, Karayaka and Bafra locations, respectively (Figure 1; Table 3). The results of soil analysis for the experimental sites also support this information. The experimental site with the highest organic matter content (2.36\%) was in Gümüşhacıköy. Soils in Bafra (1.76\%) and Karayaka (1.43\%) were lower than Gümüşhacıköy, while higher than Evciler (0.95\%) (Table 1).
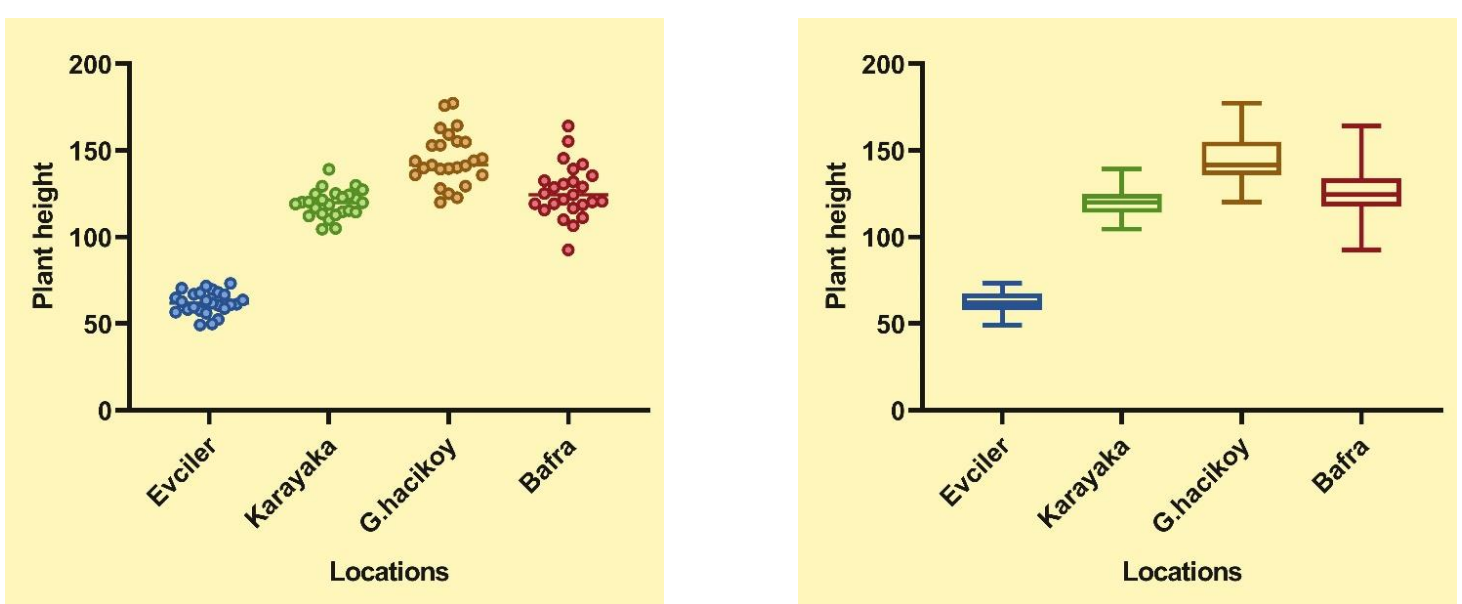

Figure 1. Variation of plant height according to averages of locations of different tobacco genotypes.

Şekil 1. Farklı tütün genotiplerinin lokasyon ortalamalarına göre bitki boyu varyasyonları.

\section{Number of Leaves (per plant)}

The mean number of leaves and the analysis results for different tobacco lines and varieties were given in Table 3. The difference in locations had a significant impact $(p<0.01)$ on the number of leaves. The number of leaves in the previous studies was reported between 25 and 30 (Camas, 1998) and 30-35 leaves per plant (Peksuslu et al., 2012) in Canik 190-5 cultivar. The number of leaves for Nail population in this study was between 24.47 and 30.33 leaf plant ${ }^{-1}$, and for Canik 190-5 variety between 23.80 and 37.07 leaf plant $^{-1}$. Xanthi $2 \mathrm{~A}$ variety has been used as plant material in some studies and the number of leaves was reported ranging from 28 to 30 leaf plant $^{-1}$ (ATEA, 2012), from 31 to 35 leaf plant $^{-1}$ (Kurt and Ayan, 2014), from 26.5 to 27.5 leaf plant $^{-1}$ (Kinay and Yilmaz, 2016). Similarly, the number of leaves for Xanthi 81 variety was between 30 and 32 leaf plant ${ }^{-1}$ in ATEA (2012) and between 26.9 and 28.5 leaf plant $^{-1}$ in Ozcan (2014). The number of leaves for Xanthi 2A was found between 21.83 and 30.87 leaf plant $^{-1}$ and for Xanthi 81 between 22.73 and 39.30 leaf plant $^{-1}$ (Figure 2; Table 3). The results revealed that the number of leaves that can increase or decrease in parallel with the plant height may vary with the changing environmental conditions, and our results were in accordance with the previous studies.

Camas et al. (2009b) reported that the number of commonly grown Basma type tobacco in Erbaa was between 25.30 and 34.80 per plant. The average number of commercial leaves per plant for Basma tobacco was reported as 30 (Camas et al., 2011; Yilmaz and Kinay, 2011). The average leaf number for genotypes was between 27.20 and 34.88 leaf plant $^{-1}$, and for the locations was between 24.89 and 34.56 leaf plant $^{-1}$ which were compatible with previous studies (Figure 2; Table 3).

The number of leaves is a criterion related to the genetic structure, however, the different products with various characteristics can be obtained in oriental tobacco by using the same seed due to the effect of environmental factors (Peksuslu et al., 2012). A significant part of the variation in autogamy plants was attributed to the environmental conditions (Usturali et al., 1998). The same type of seeds can produce higher number of leaves in a location rich in available nutrient and water compared to the environment that has nutrient deficiency and lack of available water (Kinay and Yilmaz, 2016). Changes in the number of leaves in plants of the same genotype under varying environmental conditions can be seen in Table 3.

The number of leaves varied between 21.83 and 47.10 leaf plant ${ }^{-1}$. Similar to the plant height, Gümüşhacıköy is the location where the highest number of leaves is obtained. The highest number of leaves, similar to the plant height was obtained in Gümüşhacıköy location. The greater light intensity in high altitudes 
reported causing the formation of high number of leaves (Sencar and Gokmen, 2004). The extreme cases such as the increase in temperature increases the number of leaves in upper hand groups of plant, which shades the lower leaves (Smith et al., 2004).

Table 3. Data about the plant height and number of leaves characters of genotypes and results of statistical analysis according to locations.

Çizelge 3. Genotiplerin bitki boyu ve yaprak sayısı ile ilgili verileri ve lokasyonlara göre istatistiksel analiz sonuçları.

\begin{tabular}{|c|c|c|c|c|c|c|c|c|c|c|}
\hline \multirow{2}{*}{ Genotypes } & \multicolumn{5}{|c|}{ Plant height (cm) } & \multicolumn{5}{|c|}{ Number of leaves (per plant) } \\
\hline & Evciler & Karayaka & G.Hacıköy & Bafra & Means & Evciler & Karayaka & G.Hacıköy & Bafra & Means \\
\hline ERB-5 & 60.67 af & $116.83 \mathrm{bf}$ & $135.92 \mathrm{~g}$ & $120.63 \mathrm{jm}$ & 108.51 & 24.63 af & $32.37 \mathrm{cf}$ & $33.77 \mathrm{hi}$ & 31.87 ei & 30.66 \\
\hline ERB-6 & $58.33 \mathrm{bf}$ & 110.10 ef & $140.30 \mathrm{eg}$ & $116.67 \mathrm{ln}$ & 106.35 & $25.67 \mathrm{ad}$ & $30.27 \mathrm{gk}$ & $40.10 c$ & از 29.60 & 31.41 \\
\hline ERB-7 & 61.93 af & $114.63 \mathrm{cf}$ & $152.88 d$ & $118.74 \mathrm{~km}$ & 112.05 & 24.90 ae & $32.17 \mathrm{cf}$ & $40.37 c$ & $32.87 \mathrm{de}$ & 32.58 \\
\hline ERB-9 & $69.70 \mathrm{ad}$ & 118.80 be & $153.05 \mathrm{~d}$ & $119.37 \mathrm{~km}$ & 115.23 & 25.57 ae & $31.47 \mathrm{dh}$ & $37.57 \mathrm{de}$ & از 28.37 & 30.74 \\
\hline ERB-11 & $67.10 \mathrm{ad}$ & 120.17 be & $177.32 \mathrm{a}$ & از 121.73 & 121.58 & $26.37 \mathrm{ac}$ & $30.13 \mathrm{gk}$ & $45.13 b$ & $30.50 \mathrm{fj}$ & 33.03 \\
\hline ERB-12 & $67.83 \mathrm{ad}$ & 122.33 be & $141.55 \mathrm{eg}$ & 135.46 ef & 116.80 & $25.97 \mathrm{ac}$ & 30.83 ei & $34.83 \mathrm{gi}$ & $32.60 \mathrm{df}$ & 31.06 \\
\hline ERB-13 & $57.63 \mathrm{cf}$ & $124.53 \mathrm{bd}$ & $141.35 \mathrm{eg}$ & $132.66 \mathrm{fg}$ & 114.04 & 23.67 cf & $33.73 b c$ & $32.97 \mathrm{ij}$ & $32.37 \mathrm{eg}$ & 30.68 \\
\hline ERB-14 & 61.23 af & $129.87 \mathrm{ab}$ & $155.32 \mathrm{~cd}$ & $145.52 c$ & 122.99 & 24.77 af & $34.80 \mathrm{ab}$ & $39.30 \mathrm{~cd}$ & $35.70 \mathrm{~b}$ & 33.64 \\
\hline ERB-15 & 61.00 af & $124.93 \mathrm{bd}$ & $120.02 \mathrm{i}$ & $155.33 \mathrm{~b}$ & 115.32 & 24.40 af & $31.67 \mathrm{dg}$ & $30.60 \mathrm{~km}$ & $35.67 \mathrm{~b}$ & 30.58 \\
\hline ERB-16 & 64.93 ae & $139.10 \mathrm{a}$ & $145.38 \mathrm{e}$ & $164.22 \mathrm{a}$ & 128.41 & $26.87 \mathrm{ab}$ & $36.13 a$ & $35.17 \mathrm{fh}$ & $40.73 \mathrm{a}$ & 34.73 \\
\hline ERB-17 & 63.47 ae & $113.60 \mathrm{df}$ & $135.76 \mathrm{~g}$ & 111.36 no & 106.05 & 25.23 ae & $28.73 \mathrm{jk}$ & 33.43 hj & $28.23 \mathrm{kl}$ & 28.91 \\
\hline ERB-18 & $56.07 \mathrm{df}$ & $104.63 \mathrm{f}$ & $129.42 \mathrm{~h}$ & 110.12 o & 100.06 & $24.17 \mathrm{bf}$ & 27.931 & $28.87 \mathrm{mn}$ & $27.83 \mid$ & 27.20 \\
\hline ERB-19 & $58.83 \mathrm{bf}$ & $115.43 \mathrm{cf}$ & $125.14 \mathrm{hi}$ & $119.39 \mathrm{~km}$ & 104.70 & 25.17 ae & $30.20 \mathrm{gk}$ & $29.17 \ln$ & 29.17 jl & 28.43 \\
\hline ERB-21 & 73.27 a & $129.40 \mathrm{ab}$ & $159.25 \mathrm{bc}$ & $142.06 \mathrm{~cd}$ & 125.99 & $27.30 \mathrm{a}$ & $32.63 \mathrm{ce}$ & 31.70 jk & $32.03 \mathrm{eh}$ & 30.92 \\
\hline ERB-23 & 59.63 bf & 121.57 be & 144.21 ef & $132.00 \mathrm{fg}$ & 114.35 & $24.07 \mathrm{bf}$ & $30.17 \mathrm{gk}$ & $36.07 \mathrm{eg}$ & $32.83 \mathrm{de}$ & 30.78 \\
\hline ERB-25 & $71.70 \mathrm{ab}$ & $127.30 \mathrm{ac}$ & $128.15 \mathrm{~h}$ & $130.68 \mathrm{gh}$ & 114.46 & $26.60 \mathrm{ac}$ & $33.53 b c$ & $30.00 \mathrm{~km}$ & $33.10 \mathrm{ce}$ & 30.81 \\
\hline ERB-26 & $68.17 \mathrm{ad}$ & $125.27 \mathrm{bd}$ & $122.81 \mathrm{i}$ & $128.66 \mathrm{gi}$ & 111.23 & $26.03 \mathrm{ac}$ & $31.00 \mathrm{di}$ & $25.83 \circ$ & $32.60 \mathrm{df}$ & 28.87 \\
\hline ERB-27 & 62.73 af & $112.17 \mathrm{df}$ & $.56 \mathrm{fg}$ & 106.53 o & & 25.10 ae & & & 29.83 il & 27.72 \\
\hline ERB-30 & $70.53 \mathrm{ac}$ & $112.77 \mathrm{df}$ & $154.85 \mathrm{~cd}$ & 125.30 hj & 115.86 & 25.53 ae & $30.57 \mathrm{fj}$ & $34.00 \mathrm{hi}$ & 29.83 il & 29.98 \\
\hline ERB-35 & 63.70 ae & 120.33 be & $176.02 \mathrm{a}$ & $129.01 \mathrm{gi}$ & 122.27 & 24.93 ae & $32.73 \mathrm{~cd}$ & $47.10 \mathrm{a}$ & $34.73 \mathrm{bd}$ & 34.88 \\
\hline ERB-38 & 52.57 ef & 119.13 be & $162.96 \mathrm{~b}$ & $120.35 \mathrm{jm}$ & 113.75 & 22.50 ef & $29.57 \mathrm{hl}$ & 36.77 ef & $30.10 \mathrm{hk}$ & 29.73 \\
\hline Xanthi 2A & $49.97 \mathrm{f}$ & 119.97 be & $139.28 \mathrm{fg}$ & $92.63 p$ & 100.46 & $21.83 f$ & 29.30 il & $30.87 \mathrm{kl}$ & از 28.33 & 27.58 \\
\hline Nail & $66.80 \mathrm{ad}$ & 123.00 be & $143.81 \mathrm{ef}$ & $115.64 \mathrm{mn}$ & 112.31 & 24.47 af & $29.67 \mathrm{hl}$ & 27.40 no & $30.33 \mathrm{gk}$ & 27.97 \\
\hline Canik 190-5 & $56.67 \mathrm{df}$ & $114.53 \mathrm{cf}$ & $164.50 \mathrm{~b}$ & $139.30 \mathrm{de}$ & 118.75 & $23.80 \mathrm{bf}$ & $28.43 \mathrm{kl}$ & 37.07 ef & $35.03 \mathrm{bc}$ & 31.08 \\
\hline Xanthi 81 & $49.33 \mathrm{f}$ & $105.03 \mathrm{f}$ & $139.87 \mathrm{eg}$ & $124.54 \mathrm{ik}$ & 104.69 & $22.73 \mathrm{df}$ & $29.63 \mathrm{hl}$ & $39.30 \mathrm{~cd}$ & $33.23 \mathrm{ce}$ & 31.23 \\
\hline Means & 62.15 & 119.42 & 145.15 & 126.32 & 113.26 & 24.89 & 31.08 & 34.56 & 31.90 & 30.61 \\
\hline Std. means & 55.69 & 115.63 & 146.87 & 118.03 & 109.05 & 23.21 & 29.26 & 33.66 & 31.73 & 29.46 \\
\hline Lines means & 63.38 & 120.14 & 144.82 & 127.90 & 114.06 & 25.21 & 31.43 & 34.73 & 31.93 & 30.83 \\
\hline LSD $_{0.05}$ & 11.23 & 11.01 & 5.01 & 5.13 & & 2.55 & 1.64 & 1.75 & 1.87 & \\
\hline CV (\%) & 11.01 & 5.61 & 2.10 & 2.47 & & 6.23 & 3.21 & 3.09 & 3.58 & \\
\hline \multicolumn{10}{|c|}{ Mean square and significance } & $d f$ \\
\hline & $124.65^{\star *}$ & $186.19^{* \star}$ & $698.21^{\star \star}$ & $714.78^{\star *}$ & & $5.38^{* *}$ & $12.42^{\star \star}$ & $89.57^{\star \star}$ & $26.86^{\star \star}$ & 24 \\
\hline Error & 46.76 & 45.01 & 9.29 & 9.77 & & 2.40 & 1.00 & 1.14 & 1.30 & 48 \\
\hline
\end{tabular}

*Values followed by different letters in each column are significantly different ( $\left.{ }^{*} p<0.05\right)$ according to Duncan test; Std. means: Standarts means; LSD: Least significant difference; CV: Coefficent of variation; $d f$ : Degree of freedom; ${ }^{* \star} p<0.01$
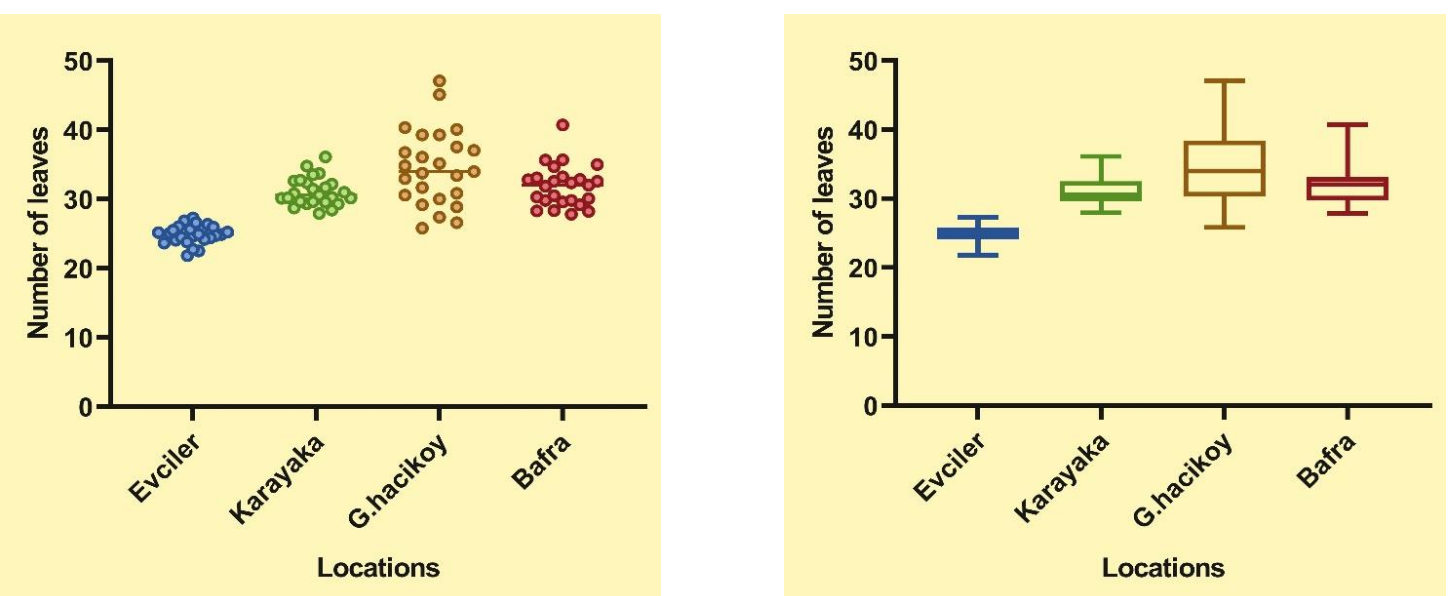

Figure 2. Variation of number of leave according to averages of locations of different tobacco genotypes. Şekil 2. Farklı tütün genotiplerinin lokasyon ortalamalarına göre yaprak sayısı varyasyonları. 
Soil organic matter content was higher in Gümüşhacıköy was higher compared to other locations. Planting of seedlings during spring rains, continuity of the rains for a while after the planting, and more favorable growth and development conditions compared to other locations in the transplanting and development period may explain the increase of vegetative characteristics such as the number of leaves. The number of leaves, which was 34.56 leaf plant ${ }^{-1}$ in Gümüşhacıköy, is $38.85 \%$ higher compared to the Evciler (24.89 leaf plant $\left.{ }^{-1}\right)$, 8.34\% higher compared to the Karayaka (31.08 leaf plant ${ }^{-1}$ ) and 8.34\% higher compared to the Bafra (31.90 leaf plant $^{-1}$ ) (Table 3). Sekin (1986) reported that drought following early rains caused a weak root structure and punier plant development. Similarly, Cakir and Cebi (2006) reported that water stress during vegetative rapid growth and product formation periods reduced the plant height, number of leaves and leaf area. Fewer number of leaves in Evciler might be related to the drought, which was identified during the study and tried to be compensated by irrigation, and the weak soil structure.

\section{Leaf Width (cm)}

The mean leaf widths and analysis results of different tobacco lines and varieties were given in Table 4. The results indicated that location has a significant impact $(p<0.01)$ on leaf width of the genotypes. The mean leaf width of the lines were between 9.07 and $13.77 \mathrm{~cm}$. These values are compatible with the previous studies reporting leaf width in the range of 9.50-14.50 cm (Camas et al., 2009b; Yilmaz and Kinay, 2011).

The average leaf width of Nail populations in Erbaa (Kinay, 2014) and Bafra (Caliskan, 2006) conditions (12.08 and 9.27, respectively) was similar to our findings (between 9.44 and $14.75 \mathrm{~cm}$, mean $12.71 \mathrm{~cm}$ ).

The leaf width of Xanthi 2A variety was determined as $9.50 \mathrm{~cm}$ (Kinay and Yilmaz, 2016) and $8.65 \mathrm{~cm}$ (Kurt and Ayan, 2014), and for Xanthi 81 as $10.70 \mathrm{~cm}$ (Ozcan, 2014). The mean leaf width of the Xanthi Djebel XDj-1 variety was reported as $8.4 \mathrm{~cm}$ (Korubin-Aleksoska et al., 2014). The mean leaf widths of Xanthi 2A and Xanthi 81 varieties were 12.42 and $11.37 \mathrm{~cm}$, respectively. The differences in leaf width con be attributed to the higher number of experimental sites compared to the previous studies. Because the increase in leaf width was observed in locations other than Erbaa (Evciler, Karayaka) conditions where previous studies have been carried out (Figure 3; Table 4).
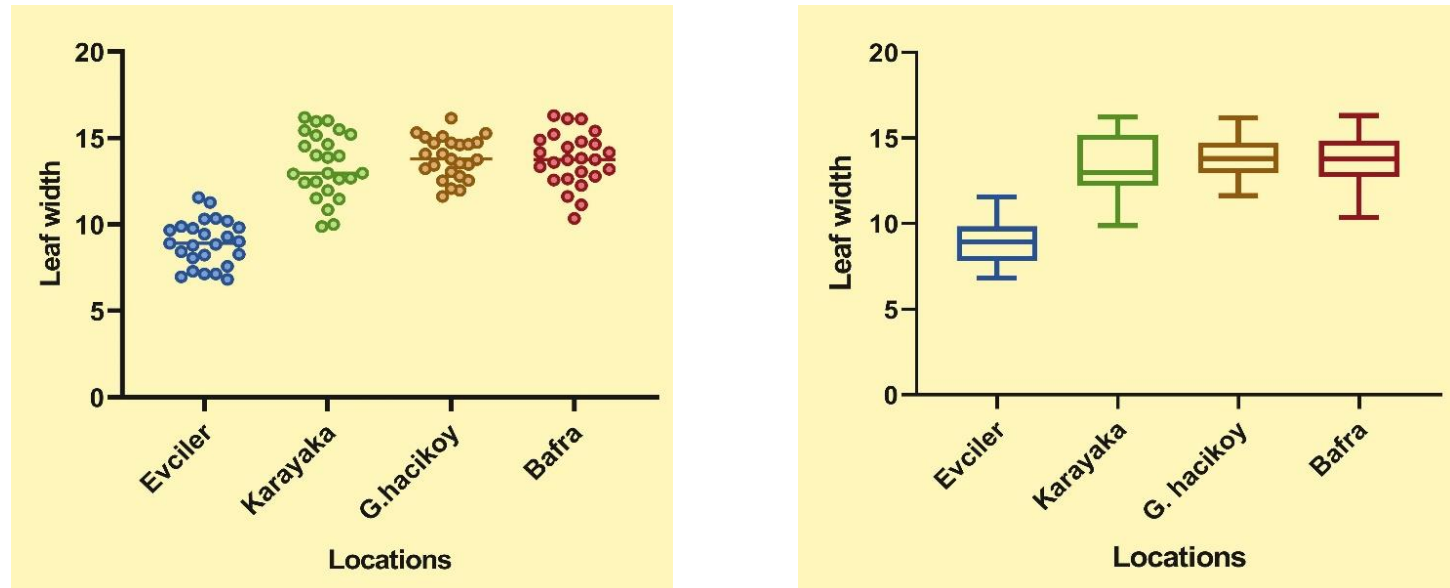

Figure 3. Variation of leaf width according to averages of locations of different tobacco genotypes. Şekil 3. Farklı tütün genotiplerinin lokasyon ortalamalarına göre yaprak eni varyasyonları.

Oriental tobaccos have small to medium leaf sizes. The increase in leaf sizes increases the intercellular spaces and causes the number of glandular hairs in which the aromatic substances on the lower and upper leaf surfaces are secreted (Zorba, 2008). The Nail population, Canik 190-5 variety, Xanthi 2A and Xanthi 81, as well as all the tobacco types grown in the Central Black Sea region, are considered genotypes with small-medium leaf size group (Camas, 1998; Peksuslu, 1998; Camas et al., 2011; ATEA, 2012; Peksuslu et al., 2012).

Leaf yield of tobacco has a direct relationship with the length of the plant, the number of leaves per plant, the width and length of the leaves (Butorac et al., 1999). Therefore, researchers reported that the leaf width has an increasing effect on the wet or tobacco yield (Dyulgerski and Dimanov, 2012). Aytac (2016) also indicated a positive relationship between leaf width and tobacco yield. Similar to the other characteristics, leaf width is affected by environmental changes and may differ depending on the presence of stress factors or the appropriate growth conditions. 
The average leaf width was $12.49 \mathrm{~cm}$, and similar to the plant height and leaf number, Gümüşhacıköy location provided the highest contribution to the increase in leaf width and followed by Bafra location (Figure 3; Table 4). The increase in leaf width was attributed to the similar reasons as the plant height and the number of leaves. The organic matter content in Gümüşhacıköy and Bafra locations were higher than the other two locations. The precipitation in all locations was not balanced, however, the precipitation during the vegetation period in Gümüşhacıköy was $34.3 \mathrm{~mm}$ higher than the other locations (Table 2).

Table 4. Data about the leaf width and leaf lenght characters of genotypes and results of statistical analysis according to locations.

Çizelge 4. Genotiplerin yaprak eni ve yaprak boyu ile ilgili verileri ve lokasyonlara göre istatistiksel analiz sonuçları.

\begin{tabular}{|c|c|c|c|c|c|c|c|c|c|c|}
\hline \multirow{2}{*}{ Genotypes } & \multicolumn{5}{|c|}{ Leaf width $(\mathrm{cm})$} & \multicolumn{5}{|c|}{ Leaf lenght $(\mathrm{cm})$} \\
\hline & Evciler & Karayaka & G.Hacıköy & Bafra & Means & Evciler & Karayaka & G.Hacıköy & Bafra & Means \\
\hline ERB-5 & $6.97 \mathrm{gh}$ & $10.00 \mathrm{~g}$ & $12.56 \mathrm{fi}$ & $12.79 \mathrm{hj}$ & 10.58 & $13.73 \mathrm{gi}$ & $22.31 \mathrm{df}$ & $21.65 \mathrm{fh}$ & 24.78 af & 20.62 \\
\hline ERB-6 & $9.88 \mathrm{ad}$ & $12.97 \mathrm{ag}$ & $14.08 \mathrm{bf}$ & از 11.63 & 12.14 & $15.48 \mathrm{di}$ & $22.37 \mathrm{df}$ & 24.52 ae & $22.89 \mathrm{eg}$ & 21.31 \\
\hline ERB-7 & $8.23 \mathrm{ch}$ & $11.47 \mathrm{eg}$ & 13.06 ei & $12.65 \mathrm{hk}$ & 11.35 & 14.52 ei & $23.13 \mathrm{cf}$ & $23.37 \mathrm{cg}$ & $23.26 \mathrm{dg}$ & 21.07 \\
\hline ERB-9 & $11.28 \mathrm{ab}$ & $15.16 \mathrm{ad}$ & $13.43 \mathrm{dh}$ & $12.26 \mathrm{ik}$ & 13.04 & $19.45 \mathrm{ab}$ & $27.27 \mathrm{ad}$ & $25.02 \mathrm{ad}$ & $22.80 \mathrm{eg}$ & 23.64 \\
\hline ERB-11 & $8.85 \mathrm{ch}$ & $12.69 \mathrm{ag}$ & $13.47 \mathrm{dh}$ & $13.75 \mathrm{di}$ & 12.19 & $16.49 \mathrm{bh}$ & 25.34 af & 24.82 ae & $24.54 \mathrm{bf}$ & 22.80 \\
\hline ERB-12 & $7.14 \mathrm{gh}$ & $10.86 \mathrm{fg}$ & $14.09 \mathrm{bf}$ & $13.05 \mathrm{gj}$ & 11.29 & $13.01 \mathrm{i}$ & 21.58 ef & 24.09 af & 25.11 af & 20.95 \\
\hline ERB-13 & 9.67 ae & $12.93 \mathrm{ag}$ & $12.80 \mathrm{fi}$ & $13.60 \mathrm{di}$ & 12.25 & 17.50 af & 25.74 af & $23.37 \mathrm{cg}$ & 24.84 af & 22.86 \\
\hline ERB-14 & $6.83 \mathrm{~h}$ & $11.97 \mathrm{dg}$ & $13.80 \mathrm{bg}$ & 10.36 I & 10.74 & $14.69 \mathrm{di}$ & 25.22 af & $23.86 \mathrm{bf}$ & $20.78 \mathrm{~g}$ & 21.14 \\
\hline ERB-15 & $8.92 \mathrm{ch}$ & 13.98 af & $11.98 \mathrm{hi}$ & $13.77 \mathrm{di}$ & 12.16 & $16.13 \mathrm{ci}$ & $27.75 \mathrm{ac}$ & $22.22 \mathrm{eg}$ & $26.48 \mathrm{ad}$ & 23.14 \\
\hline ERB-16 & $11.57 \mathrm{a}$ & $16.03 \mathrm{ab}$ & $11.63 \mathrm{i}$ & $16.13 \mathrm{ab}$ & 13.84 & $20.23 a$ & $28.87 \mathrm{ab}$ & $21.73 \mathrm{fh}$ & $28.09 a$ & 24.73 \\
\hline ERB-17 & $10.32 \mathrm{ac}$ & $16.21 \mathrm{a}$ & $12.54 \mathrm{fi}$ & $15.42 \mathrm{ac}$ & 13.62 & $19.30 \mathrm{ac}$ & $27.82 \mathrm{ac}$ & $20.94 \mathrm{gh}$ & 26.10 ae & 23.54 \\
\hline ERB-18 & $8.28 \mathrm{ch}$ & 14.54 ae & $14.61 \mathrm{ae}$ & 14.90 ae & 13.08 & $15.07 \mathrm{di}$ & 25.51 af & $23.72 \mathrm{bf}$ & 25.84 ae & 22.54 \\
\hline ERB-19 & $10.36 \mathrm{ac}$ & $15.44 \mathrm{ad}$ & 14.74 ae & 14.79 af & 13.83 & 17.26 af & 25.17 af & 24.23 af & 25.85 ae & 23.13 \\
\hline ERB-21 & $10.20 \mathrm{ac}$ & $15.97 \mathrm{ac}$ & $12.09 \mathrm{gi}$ & $16.31 \mathrm{a}$ & 13.64 & 17.41 af & 28.93 a & $19.60 \mathrm{~h}$ & $27.32 \mathrm{ab}$ & 23.31 \\
\hline ERB-23 & $8.07 \mathrm{dh}$ & $12.65 \mathrm{ag}$ & $15.33 \mathrm{ab}$ & 13.36 ei & 12.35 & $15.48 \mathrm{di}$ & 25.62 af & $26.07 \mathrm{ab}$ & 25.86 ae & 23.26 \\
\hline ERB-25 & $9.02 \mathrm{cg}$ & $15.22 \mathrm{ad}$ & 13.23 ei & $15.22 \mathrm{ad}$ & 13.17 & $16.25 \mathrm{bi}$ & 26.11 af & $22.84 \mathrm{dg}$ & 25.62 ae & 22.71 \\
\hline ERB-26 & $9.30 \mathrm{bf}$ & $12.97 \mathrm{ag}$ & $13.55 \mathrm{ch}$ & $16.12 a b$ & 12.98 & $15.51 \mathrm{di}$ & $22.70 \mathrm{cf}$ & $26.13 a b$ & $26.46 \mathrm{ad}$ & 22.70 \\
\hline ERB-27 & $9.82 \mathrm{ad}$ & $15.51 \mathrm{ad}$ & $15.10 \mathrm{ad}$ & $14.18 \mathrm{ch}$ & 13.65 & $17.04 \mathrm{ag}$ & $27.69 \mathrm{ac}$ & $25.70 \mathrm{ac}$ & $23.86 \mathrm{cg}$ & 23.57 \\
\hline ERB-30 & $9.78 \mathrm{ad}$ & 14.01 af & 14.72 ae & $14.48 \mathrm{cg}$ & 13.25 & 17.45 af & $23.68 \mathrm{bf}$ & 26.67 a & $26.69 \mathrm{ac}$ & 23.62 \\
\hline ERB-35 & $8.79 \mathrm{ch}$ & 14.65 ae & $13.77 \mathrm{bg}$ & $12.58 \mathrm{hk}$ & 12.45 & $16.04 \mathrm{ci}$ & 24.47 af & $25.61 \mathrm{ac}$ & $22.06 \mathrm{fg}$ & 22.05 \\
\hline ERB-38 & $7.30 \mathrm{fh}$ & 13.88 af & $16.16 \mathrm{a}$ & $11.14 \mathrm{kl}$ & 12.12 & $14.23 \mathrm{fi}$ & 26.29 ae & $26.77 \mathrm{a}$ & $20.86 \mathrm{~g}$ & 22.04 \\
\hline Xanthi 2A & $7.58 \mathrm{eh}$ & $12.43 \mathrm{cg}$ & $15.05 \mathrm{ad}$ & $14.64 \mathrm{bg}$ & 12.42 & 14.63 ei & 25.65 af & $26.13 \mathrm{ab}$ & 25.72 ae & 23.03 \\
\hline Nail & 9.44 be & $12.48 \mathrm{bg}$ & 14.75 ae & $14.17 \mathrm{ch}$ & 12.71 & 17.79 ae & 23.91 af & $25.56 \mathrm{ac}$ & 25.18 af & 23.11 \\
\hline Canik 190-5 & $8.43 \mathrm{ch}$ & $11.52 \mathrm{eg}$ & 15.28 ac & $13.21 \mathrm{fj}$ & 12.11 & $18.02 \mathrm{ad}$ & 25.81 af & $26.14 a b$ & $26.62 \mathrm{ad}$ & 24.15 \\
\hline Xanthi 81 & $7.14 \mathrm{gh}$ & $9.88 \mathrm{~g}$ & $14.64 \mathrm{ae}$ & $13.84 \mathrm{ci}$ & 11.37 & 13.19 hi & $20.94 \mathrm{f}$ & $26.15 \mathrm{ab}$ & $24.63 \mathrm{bf}$ & 21.23 \\
\hline Means & 8.93 & 13.42 & 13.86 & 13.77 & 12.49 & 16.24 & 25.20 & 24.28 & 24.89 & 22.65 \\
\hline Std. means & 8.15 & 11.58 & 14.93 & 13.96 & 12.15 & 15.91 & 24.08 & 25.99 & 25.54 & 22.88 \\
\hline Lines means & 9.07 & 13.77 & 13.65 & 13.74 & 12.56 & 16.30 & 25.41 & 23.95 & 24.77 & 22.61 \\
\hline LSD $_{0.05}$ & 1.77 & 2.95 & 1.46 & 1.39 & & 2.78 & 4.29 & 2.25 & 2.81 & \\
\hline CV (\%) & 12.07 & 13.37 & 6.42 & 6.13 & & 10.44 & 10.37 & 5.65 & 6.87 & \\
\hline \multicolumn{10}{|c|}{ Mean square and significance } & $d f$ \\
\hline Genotype & $5.31^{* *}$ & $10.42^{* \star}$ & $4.21^{* *}$ & $7.05^{\star *}$ & & $11.06^{* \star}$ & $14.62^{*}$ & $11.28^{* \star}$ & $10.80^{\star *}$ & 24 \\
\hline Error & 1.16 & 3.22 & 0.79 & 0.71 & & 2.87 & 6.83 & 1.88 & 2.93 & 48 \\
\hline
\end{tabular}

*Values followed by different letters in each column are significantly different $\left({ }^{*} p<0.05\right)$ according to Duncan test; Std. means: Standarts means; LSD: Least significant difference; CV: Coefficent of variation; $d f$ : Degree of freedom; ${ }^{* \star} p<0.01$

\section{Leaf Length (cm)}

The mean leaf length values and analysis results of different tobacco lines and varieties are given in Table 4. The effect of location on leaf length was slightly important $(p<0.05)$ for Karayaka location while very important $(p<0.01)$ for other locations. The leaf length of the Basma tobacco was reported between $11.40-19.30 \mathrm{~cm}$ (Camas et al., 2009b) and 25.10-26.90 cm (Yilmaz and Kinay, 2011). The average leaf size of Basma tobacco in some other studies was $20 \mathrm{~cm}$ and considered as small-medium size leaf (Peksuslu, 1998; Camas, 1998; Camas et al., 2011). The mean leaf length of the lines measured in this study ranged between 16.24 and $25.20 \mathrm{~cm}$ and was in agreement with previous studies.

Leaf length values of the standards used ranged from 14.63 to $26.13 \mathrm{~cm}$ for Xanthi $2 \mathrm{~A}$, from 17.79 to 25.56 $\mathrm{cm}$ for Nail, from 18.02 to $26.62 \mathrm{~cm}$ for Canik 190-5 and from 13.19 to $26.15 \mathrm{~cm}$ for Xanthi 81. The leaf length of Xanthi 2A variety in Erbaa was determined between 15.40 and $20.40 \mathrm{~cm}$ (Kinay and Yilmaz, 2016) and in Bafra between 15.7 and $18.6 \mathrm{~cm}$ (Kurt and Ayan, 2014). The mean leaf length of Xanthi Djebel XDj-1 variety was reported as $17 \mathrm{~cm}$ (Korubin-Aleksoska et al., 2014). The leaf length of Nail population ranged between 17.69 
and $24.46 \mathrm{~cm}$ (Kinay, 2014), between 17.80 and $19.10 \mathrm{~cm}$ for Xanthi 81 variety (Ozcan, 2014). The leaf lengths caused by different ecological conditions are slightly different from the results of previous studies (Table 4).
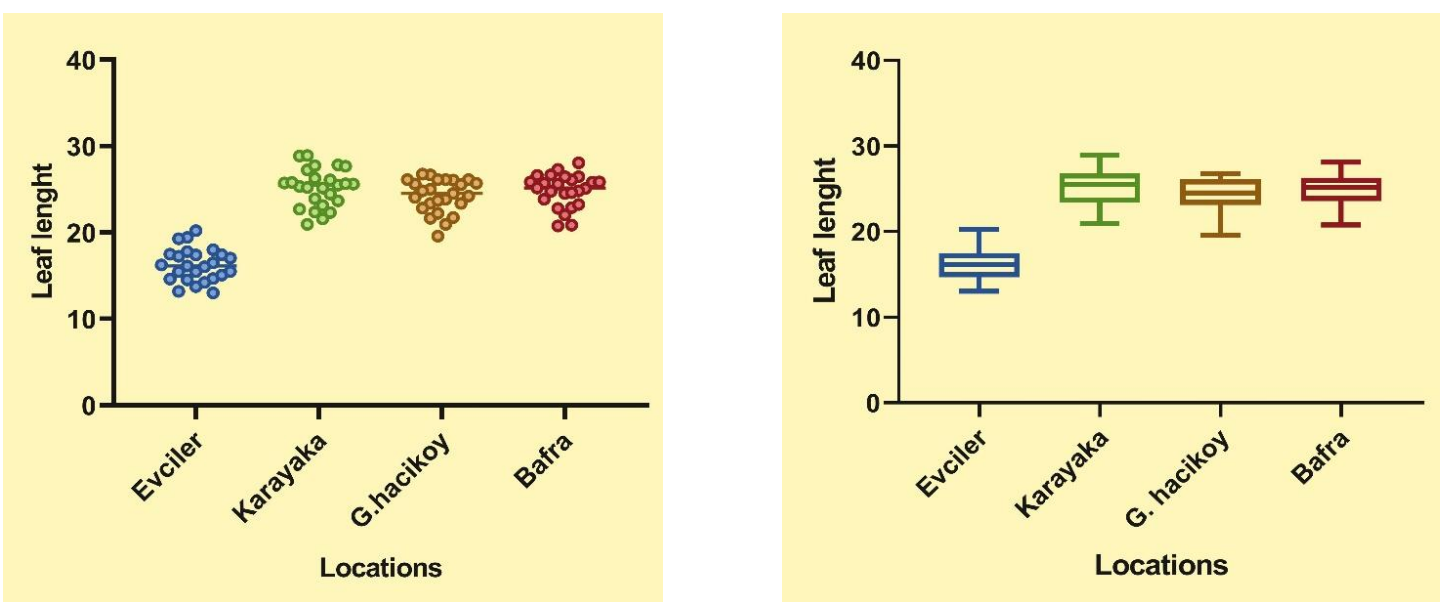

Figure 4. Variation of leaf lenght according to averages of locations of different tobacco genotypes.

Şekil 4. Farklı tütün genotiplerinin lokasyon ortalamalarına göre yaprak boyu varyasyonları.

Leaf size is an important distinctive characteristic of oriental tobaccos. For Black Sea Region tobaccos, the leaf lengths up to $15 \mathrm{~cm}$ are considered small leaf sized, those between 15 and $25 \mathrm{~cm}$ are considered as medium leaf sized and those longer than $25 \mathrm{~cm}$ are considered as broad leaf sized. All genotypes in this study are considered medium leaf sized group. In addition, leaf length was reported to have a strong positive relationship with plant height, leaf width and especially the yield (Aytac, 2016). Some researchers reported that the effect of leaf width on yield is higher compared to the leaf length (Kara, 1993; Dyulgerski and Dimanov, 2012; Kınay, 2014). Sencar and Gokmen (2004) reported that ecology in addition to the ecology has significant impact on the leaf length. The ecology has also been considered an important feature affecting the tobacco yield along with plant height, leaf width and the number of leaves (Butorac et al., 2004; Gixhari and Sulovari, 2010); therefore, investigated as an important feature in many studies conducted on tobacco.

The overall average leaf length in this study was $22.65 \mathrm{~cm}$. The highest leaf height was measured in Karakaya location, unlike plant height, number of leaves and leaf width, followed by Bafra and Gümüşhacıköy. The lowest leaf length as in plant height, leaf number and leaf width values were measured in Evciler, which had the lowest soil organic material and more calcareous characteristics than other locations. Since Evciler and Karakaya were located within the same district border, the climate data was used common for both locations. However, Evciler location had a drier season than Karayaka during the research period. Because the total rainfall in Bafra and Karayaka locations was $222.15 \mathrm{~mm}$ during the vegetation period and $256.50 \mathrm{~mm}$ in Gümüşhacıköy location (Table 2). Therefore, the drought that followed the precipitation in Evciler location had a negative effect on the development period of the vegetative parts, shortened the vegetation (Cakir and Cebi, 2006), and leaf length as in the plant height, leaf number and leaf width parameters has also decreased (Figure 4; Table 4).

\section{Yield ( $\left.\mathrm{kg} \mathrm{da}^{-1}\right)$}

The mean yield values and the results of analysis for the different tobacco lines and varieties were given in Table 5. The effect of location on the yields of genotypes was slightly significant $(p<0.05)$ in Gümüşhacıköy and very important $(p<0.01)$ in other locations.

Plant height, number of leaves, leaf width and leaf length are the important characteristics affecting the tobacco yield (Butorac et al., 1999). The yield is generally low in representatives of quality smoking oriental tobacco. The number of leaves sometimes up to 100 may indicate an increase in yield without decreasing the quality, while the increase in leaf sizes decreases the quality. The variation in leaf yield occurred parallel to the plant height, leaf number and leaf sizes of genotypes. The increasing effect of leaf length on yield is less than the effect of leaf width (Dyulgerski and Dimanov, 2012) which is due to the additive gene effect of leaf width character (Kinay, 2014). Therefore, the effect of variability in leaf length on yield was low, and the effects of plant height, number of leaves and leaf width were higher. 
The variation in yield and related characteristics of local tobacco populations which have been adapted to the ecology where it is grown over time and become ecotype, is important for the selection. The spread of foreign origin varieties to meet the sector needs, co-production of previously existing types with the foreign origin varieties, and transition of seedling and seed led to the development of ecotypes adapted to the region. The yield values during this period were determined between 77 and $148 \mathrm{~kg} \mathrm{da}^{-1}$ (Camas et al., 2009b). The mean yield values reported by Kinay (2014), who carried out breeding studies in Basma type tobacco in Erbaa and Bafra, were between 132.93 and $150.24 \mathrm{~kg} \mathrm{da}^{-1}$ in Bafra and 140.26 and $168.64 \mathrm{~kg} \mathrm{da}^{-1}$ in Erbaa. The tobacco yields in the for 2014, 2015 and 2016 annual reports of TAPDK were ranging from 94.04 to $100.55 \mathrm{~kg}$ $\mathrm{da}^{-1}$ in Amasya and from 89.44 to $98.14 \mathrm{~kg} \mathrm{da}^{-1}$ in Tokat (TADB, 2019). The yield values in this study had a considerable high variation ranging from $79.17-237.33 \mathrm{~kg} \mathrm{da}^{-1}$. The yield values obtained are clearly high, considering the yield values reported in previous studies and official records.

Table 5. Data about the yield character of genotypes and results of statistical analysis according to locations. Çizelge 5. Genotiplerin verim ile ilgili verileri ve lokasyonlara göre istatistiksel analiz sonuçları.

\begin{tabular}{|c|c|c|c|c|c|}
\hline \multirow{2}{*}{ Genotypes } & \multicolumn{5}{|c|}{ Yield $\left(\mathrm{kg} \mathrm{da}^{-1}\right)$} \\
\hline & Evciler & Karayaka & G.Hacıköy & Bafra & Means \\
\hline ERB-5 & $107.98 \mathrm{fj}$ & 162.41 be & 200.32 ae & $201.07 \mathrm{bg}$ & 167.94 \\
\hline ERB-6 & 146.32 b & 159.81 ce & 208.14 ae & 209.00 ae & 180.82 \\
\hline ERB-7 & $134.24 \mathrm{bd}$ & $196.97 \mathrm{ac}$ & 211.20 ae & 203.59 af & 186.50 \\
\hline ERB-9 & 161.78 a & $192.64 \mathrm{ad}$ & 216.47 ae & 201.92 bf & 193.20 \\
\hline ERB-11 & $121.27 \mathrm{dg}$ & 179.07 be & 207.39 ae & $195.48 \mathrm{ch}$ & 175.80 \\
\hline ERB-12 & 95.46 jl & 177.77 be & $222.10 \mathrm{ad}$ & $198.06 \mathrm{bh}$ & 173.35 \\
\hline ERB-13 & $97.19 \mathrm{jk}$ & $210.13 a b$ & 226.23 ac & 193.40 ei & 181.74 \\
\hline ERB-14 & $112.56 \mathrm{fi}$ & 182.30 be & 201.09 ae & $179.21 \mathrm{gi}$ & 168.79 \\
\hline ERB-15 & $116.81 \mathrm{eh}$ & $196.30 \mathrm{ac}$ & 174.05 e & $218.75 \mathrm{ab}$ & 176.47 \\
\hline ERB-16 & 129.36 ce & 207.46 ac & 204.01 ae & 226.11 a & 191.74 \\
\hline ERB-17 & $100.89 \mathrm{ik}$ & 164.38 be & $223.80 \mathrm{ad}$ & 191.71 ei & 170.19 \\
\hline ERB-18 & $119.49 \mathrm{eh}$ & 200.37 ac & 214.45 ae & $214.65 \mathrm{ad}$ & 187.24 \\
\hline ERB-19 & $140.26 \mathrm{bc}$ & $195.92 \mathrm{ac}$ & 183.92 be & 205.21 af & 181.33 \\
\hline ERB-21 & 166.63 a & $205.31 \mathrm{ac}$ & $224.94 \mathrm{ac}$ & $217.20 \mathrm{ac}$ & 203.52 \\
\hline ERB-23 & $82.22 \mathrm{~lm}$ & 166.96 be & 193.04 ae & $215.01 \mathrm{ad}$ & 164.31 \\
\hline ERB-25 & $140.84 \mathrm{bc}$ & $197.54 \mathrm{ac}$ & 180.55 ce & $201.03 \mathrm{bg}$ & 179.99 \\
\hline ERB-26 & $122.64 \mathrm{df}$ & 174.95 be & 200.01 ae & 211.61 ae & 177.30 \\
\hline ERB-27 & $122.42 \mathrm{df}$ & $237.33 a$ & $231.91 \mathrm{a}$ & 211.20 ae & 200.72 \\
\hline ERB-30 & $140.68 \mathrm{bc}$ & 205.85 ac & $228.48 \mathrm{ab}$ & 207.85 ae & 195.71 \\
\hline ERB-35 & $114.22 \mathrm{fi}$ & $201.17 \mathrm{ac}$ & 233.54 a & $183.49 \mathrm{fi}$ & 183.11 \\
\hline ERB-38 & $90.19 \mathrm{~km}$ & 165.57 be & 238.98 a & $217.11 \mathrm{ac}$ & 177.96 \\
\hline Xanthi 2A & 79.17 m & 147.66 de & $178.09 \mathrm{de}$ & $172.89 \mathrm{i}$ & 144.46 \\
\hline Nail & 105.88 hj & 171.73 be & 217.81 ae & $177.58 \mathrm{hi}$ & 168.25 \\
\hline Canik 190-5 & $107.34 \mathrm{gj}$ & 168.90 be & $233.04 \mathrm{a}$ & 202.18 bf & 177.87 \\
\hline Xanthi 81 & $82.11 \mathrm{Im}$ & $143.38 \mathrm{e}$ & $223.21 \mathrm{ad}$ & 190.07 ei & 159.69 \\
\hline Means & 117.52 & 184.48 & 211.07 & 201.82 & 178.72 \\
\hline Std. means & 93.63 & 157.92 & 213.04 & 185.68 & 162.57 \\
\hline Lines means & 122.07 & 189.53 & 210.70 & 204.89 & 181.80 \\
\hline LSD $_{0.05}$ & 13.00 & 39.97 & 37.83 & 19.02 & \\
\hline CV (\%) & 6.73 & 13.19 & 10.91 & 5.74 & \\
\hline \multicolumn{5}{|c|}{ Mean square and significance } & $d f$ \\
\hline Genotype & $1693.12^{\star *}$ & $1480.94^{\star \star}$ & $1038.15^{\star}$ & $576.15^{\star \star}$ & 24 \\
\hline Error & 62.69 & 592.80 & 530.92 & 134.21 & 48 \\
\hline
\end{tabular}

*Values followed by different letters in each column are significantly different $\left({ }^{*} p<0.05\right)$ according to Duncan test; Std. means: Standarts means; LSD: Least significant difference; CV: Coefficent of variation; $d f$ : Degree of freedom; ${ }^{\star *} p<0.01$

The mean yield values of the standards varied between $93.63-213.04 \mathrm{~kg} \mathrm{da}^{-1}$. The yield value of Xanthi $2 \mathrm{~A}$ under Erbaa conditions was reported between 66.90 and $127.60 \mathrm{~kg} \mathrm{da}^{-1}$ (Camas et al., 2011) and 127.34 and $139.01 \mathrm{~kg} \mathrm{da}^{-1}$ (Kinay, 2014), while under Bafra conditions between 94.00 and $127.00 \mathrm{~kg} \mathrm{da}^{-1}$ (Kurt and Ayan, 
2014) and 84.57 and $124.55 \mathrm{~kg} \mathrm{da}^{-1}$ (Kinay, 2014). Nail population had a yield between 90 and $150 \mathrm{~kg} \mathrm{da}^{-1}$ (Camas, 1998) and 126.58 and $148.50 \mathrm{~kg} \mathrm{da}^{-1}$ under Bafra conditions, and between 155.74 and $174.90 \mathrm{~kg} \mathrm{da}^{-1}$ (Kinay, 2014) under Erbaa conditions. The yield of Canik 190-5 varied between 135.55 and $168.65 \mathrm{~kg} \mathrm{da}^{-1}$ under Erbaa conditions and between 111.25 and $196.28 \mathrm{~kg} \mathrm{da}^{-1}$ under Bafra conditions (Kinay, 2014). The yield values of Xanthi 81 variety was reported between $125.00-150.00 \mathrm{~kg} \mathrm{da}^{-1}$ (ATEA, 2012) and 130.60 and $202.20 \mathrm{~kg} \mathrm{da}^{-1}$ (Ozcan, 2014). The yield values of Xanthi 2A ranged from 79.17 to $178.09 \mathrm{~kg} \mathrm{da}^{-1}$, Nail from 105.88 to $217.81 \mathrm{~kg}$ $\mathrm{da}^{-1}$, Canik 190-5 from 107.34 and $233.04 \mathrm{~kg} \mathrm{da}^{-1}$ and Xanthi 81 from 82.11 and $223.21 \mathrm{~kg} \mathrm{da}^{-1}$. Similar to the yields of tobacco lines, the yields of standards obtained in this study were higher than the yields of aforementioned studies.

The oriental tobacco has a large variation in yield resulting from the environmental conditions and different culture techniques as well as the genetic structure. Majority of (87.89\%) of the variation in tobacco yield was attributed to the changes in environmental conditions (Sadeghi et al., 2011). Water stress reduces the number of leaves, plant height, leaf area and thus the yield (Cakir and Cebi, 2006) In other words, tobacco yield is reduced while creating a defense mechanism to overcome the negative impacts of different stress sources (Lambers et al., 2000).

Production capacities of soils have a strong relationship with the organic matter content. High content of organic matter is desirable for Virginia and Burley tobaccos, which have broad blade and high yields (Er and Yildiz, 2014). The mean yield values of the locations (Figure 5, Table 5) were in agreement with the soil organic matter contents of the locations (Table 1).

The differences in altitude, vegetation period and temperature between the locations are important for leaf anatomy. Populations grown at different altitudes vary morphologically, anatomically and ecologically (Gonuz and Ozorgucu, 1999). The intensity of the incoming light and the duration of illumination increase as the altitude increases due to traveling of light through an air layer with a lower thickness. In addition, the number of solid particles and amount of water mist are also low within the air of high altitude (Kevseroglu, 1999). The relationship between light intensity and chlorophyll is positive (Ryu et al., 1989). The light intensity and the duration of illumination increase in parallel to the increase in altitude and therefore the amount of net photosynthesis increase, amount of $\mathrm{CO}_{2}$, humidity and temperature changes that affect the amount of dry matter produced (Sencar and Gokmen, 2004; Kinay, 2014).
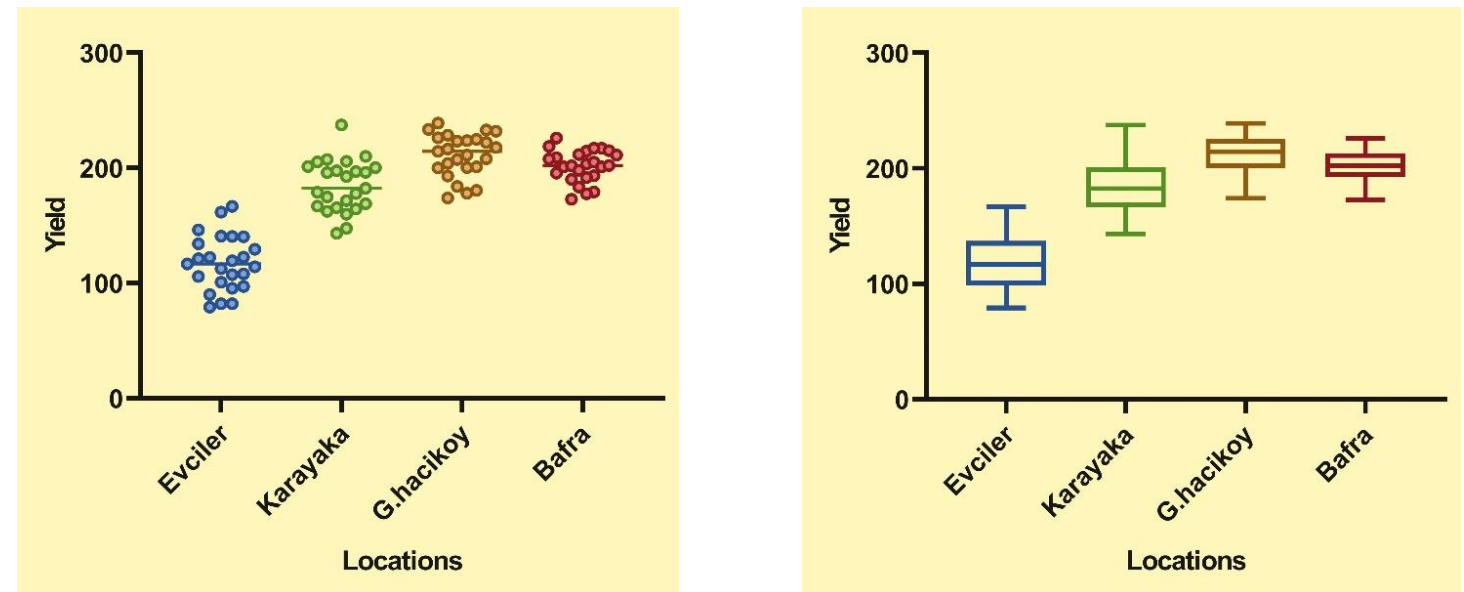

Figure 5. Variation of yield according to averages of locations of different tobacco genotypes.

Şekil 5. Farklı tütün genotiplerinin lokasyon ortalamalarına göre verim varyasyonları.

The difference in altitude causes variation in climatic conditions such as temperature, humidity, wind and precipitation, which also indirectly affects vegetation time (Akbulut et al., 2017). The cooler air compared to the long-term averages delays the transition of plants from vegetative to generative period, causes the long time vegetative plant grow and thus encourages the increase in plant height and other related features (Boydak et al., 2018). All lines identified as temporary within the scope of the study (ERB-6, ERB-7, ERB-9, ERB-16, ERB-19, ERB-21, ERB-25 and ERB-35) also had yield values than the overall yield, that confirms the above given information. Therefore, despite limited to the altitudes studied, factors delaying the vegetation have caused an observed increase in the leaf tobacco yield. The varieties were reported to produce high dry matter and starch content in cool climatic conditions and high altitudes (Ozcan, 2018). The increase in the amount of dry matter 
accumulated in the leaf increases the leaf thickness (Bruck et al., 2008), and the increased leaf thickness results in an increase in yield.

The share of precipitation in the yield variation can reach $80 \%$ (Erskine and Ashkar, 1993). Annual rainfall especially in arid and semi-arid climates is the most important climate factor affecting the yield (Floret et al., 1982). Water deficiency plays a more active role in the decrease of tobacco yield than nutrient deficiency. Because, plants can take up the nutrients only if there is enough water in soil. This is not an important problem for the plants grown in lowland, where plant roots can penetrate easily into deeper layers and use the water in the lower layers (Senbayram et al., 2005). The leaves can reach the maximum sizes in case of rapid growth and continuity of the water required to keep the plant in turgor. However, these leaves become fine and fragile. Rainfall causes to occur more elastic leaves according to irrigation. The drought after the early rainfalls results in weak root structure and puny plants, and consequently a decrease in tobacco yield. The oriental tobacco plant, which cannot tolerate the lack of water during the seedling period, needs water, especially after and during blooming period. Continuity of drought during the vegetation period decreases the yield while increasing the fragrance and aroma in the tobacco. The drought in extreme periods significantly reduces the yield even if the total precipitation in the vegetation process is sufficient (Sekin, 1986; Eser and Gecit, 2010). The variability in climate was presented in Table 2. Despite the appropriate parameters such as light, temperature and altitude, the yield obtained in the Evciler location was affected from drought, in addition, the yield also decreased due to the low organic matter content of soil.

Despite the disadvantageous of Bafra location in terms of light and temperature, soils in Bafra location had the second highest soil organic matter content (Table 1). In addition, the increase in yield can also be attributed to the high concentration of $\mathrm{CO}_{2}$ at low altitudes and the longer vegetation period in Bafra. The moisture content at low altitude locations continuously increases with evaporation occurring at open water surfaces and soils and transpiration by plants. The evaporation and transpiration ratio increase as the relative humidity of the air decreases (Eser and Gecit, 2010). The turgor of the plant does not decrease in humid conditions and growth-development continues (Kevseroglu, 1999), thus the yield increases compared to lower humid environments (Silim et al., 1993). The higher yield in Bafra is also related to the higher relative humidity (Table 2) compared to the other locations.

\section{CONCLUSION}

The tobacco plant has a high adaptability and demonstrates unique characteristics in the commonly grown regions. The quality increases in high altitude and arid lands and yield increases towards the lowlands. Despite the higher cost of raw materials compared to the other tobacco types, Central Black Sea region tobacco is the demanded type of oriental tobacco. Although the seeds of the adapted types/varieties suitable for the region can be obtained from the contracted companies, the producers continue to use the degenerated tobacco seeds obtained from their own or neighboring lands. Genotypes with substantially different characteristics from each other and from the origins appear in the region due to the transportation and exchange activities of producers, mechanical mixing and foreign pollination during the production of these seeds. Breeding studies aimed to obtain high-yielding and highly qualified varieties are needed to eliminate especially the yield and quality problems. In this study, 21 Basma type tobacco lines, which stand out with some characteristics, have been tested in four locations where the production is common, with the standards, their performances were monitored and the effects of ecological changes were determined. Clear differences in tobacco yields have been obtained among the locations and the effects of locations with different ecological conditions (light, humidity, precipitation, elevation, temperature etc.) was significant on leaf yield of tobacco. In addition to the genetic potentials, the aforementioned reasons had distinctive impacts on the yield differences of the genotypes. Producing with the desired characteristics can be possible by identifying the characteristics of the grown line/variety and providing the suitable production conditions.

\section{CONFLICT OF INTEREST}

The authors declare no conflict of interest. 


\section{DECLARATION OF AUTHOR CONTRIBUTION}

The article is summarized from the PhD thesis of the corresponding author. D.K. designed the experiments, conducted the experiments, performed the analyses, and collected the data. G.Y. and A.K. advised on the preparation of materials. D.K. did the statistics evaluations and wrote the manuscript. G.Y. and A.K. did read and edited the manuscript.

\section{ACKNOWLEDGEMENTS}

This study was supported by Republic of Turkey Tobacco and Alcohol Market Regulatory Authority (Project name: Determination of Lines with Superior Characteristics in Tokat Region Basma Type Tobaccos).

\section{REFERENCES}

Akbulut, M. K., Seker, S. S., \& Senel, G. (2017). Stoma features in leaves of Spiranthes spiralis (Orchidaceae) growing under different ecological conditions. Afyon Kocatepe University Journal of Science and Engineering, 17, 372-376.

ATEA. (2012). Basma Tobaccos Growing Technique. Aegean Exporters Associations, Aegean Tobacco Exporters Association, Izmir.

Aytac, B. (2016). Determination of Nail tobacco line performance in different locations in Bafra. MSc Thesis, Ondokuz Mayıs University, Graduate School of Sciences, Samsun.

Boydak, E., Kayantaş, B., Acar, F., \& Fırat, R. (2018). Determination of yield and yield components of some soybean (Glycine max L.) varieties at high altitudes. Harran Journal of Agricultural and Food Science, 22(4), 544-550.

Bruck, H., Jureit, C., Hermann, M., Schulz, A., \& Sattelmacher, B. (2008). Effect of water and nitrogen supply on water use efficiency and carbon isotope discrimination in Edible Canna (Canna edulis Ker-Gawler). Plant Biology, 3(4), 326-334.

Butorac, J., Vasilj, D., Kozumplik V., \& Beljo, J. (1999). Quantitative parameters of some burley tobacco traits. Rostlinna Vyroba, 45(4), 149-156.

Butorac, J., Beljo, J., \& Gunjaca, J. (2004). Study of inheritance of some agronomic and morphological traits in burley tobacco by graphic analysis of diallel cross. Plant, Soil and Environment, 50(4), 162-167.

Cakir, R. \& Cebi, U. (2006). Growth and dry matter accumulation dynamics of flue-cured tobacco under different soil moisture regimes. Journal of Agronomy, 5(1), 79-86.

Caliskan, O. (2006). Effects of different seedling production methods on yield and some quality components in tobacco (Nicotiana tabaccum L.), thyme (Origanum onites L.) and lemon balm (Melissa officinalis L.). Phd Thesis, Ondokuz Mayıs University, Graduate School of Sciences, Samsun.

Camas, N. (1998). The analysis of the inheritence ability of the some quantitative characters using line $x$ tester method in tobacco (Nicotiana tabacum L.). Phd Thesis, Ondokuz Mayıs University, Graduate School of Sciences, Samsun.

Camas, N., Caliskan, O., Odabas, M.S., \& Ayan, A.K. (2009a). The effects of organic originated fertilizer doses on yield and quality of Esendal tobacco cultivar. Turkey VIII. Field Crops Congress, Mustafa Kemal University, Hatay.

Camas, N., Karaali, H., Caliskan, O., \& Kurt, D. (2009b). Determination the yield and yield components of Basma tobacco cultivars and accessions under Gumushacikoy conditions. Turkey VIII. Field Crops Congress, Mustafa Kemal University, Hatay.

Camas, N., Karaali, H., Kurt, D., \& Kinay, A. (2011). Evaluation of quality factors for Basma kind of tobacco production in Middel Black Sea region. Turkey IX. Field Crops Congress, Uludag University, Bursa.

Dimitrova, S. (2005). Study on growth characteristics of oriental tobacco varieties under northern Bulgaria II. Ticha 117 variety. Proceedings of Jubilee Scientific Conference, Plovdiv.

Dolek, I. (1984). Some morphological characteristics of Nicotiana tabacum L. pure-line cultivars in Marmara region. Phd Thesis, Ege University, Graduate School of Sciences, Izmir.

Dyulgerski, Y., \& Dimanov, D. (2012). Study on heterozis behaviour related to the leaves size by the tobacco of burley variety group. Acta Agriculturae Serbica, 34(17), 75-82.

Er, C., \& Yildiz, M. (2014). Pleasure Plants. Ankara University publications, No: 419, Ankara. 
Erskine, W., \& Ashkar, F.E. (1993). Rainfall and temperature effects on lentil (Lens culinaris) seed yield in the mediterranean environment. The Journal of Agricultural Science, 121, 347-354.

Eser, D., \& Gecit, H.H. (2010). Ecology (Second edition). Ankara University Faculty of Agriculture publications, No:1584, Ankara.

Floret, C., Pontanier, R., \& Rambal, S. (1982). Measurement and modelling of primary production and water use in a south Tunisia steppe. Journal of Arid Environments, 5(1), 77-90.

Gixhari, B., \& Sulovari, H. (2010). Nature of inheritance and heterosis estimated on some morphological quantitative characters that influence the tobacco yield. Studii şi Cercetari, Biologie, 18, 46-50.

Gonuz, A., \& Ozorgucu, B. (1999). An investigation on the morphology, anatomy and ecology of Origanum onites L. Turkish Journal of Botany, 23, 19-32.

Kara, S. M. (1993). Diallel analysis of inheritance of some quantitative characters in tobacco (Nicotiana tabacum L.). Phd Thesis, Ondokuz Mayıs University, Graduate School of Sciences, Samsun.

Karpat, H. (1989). Studies on taxonomic characteristics of Samsun-Bafra tobacco (Nicotiana tabacum L.) cultivars. Phd Thesis, Istanbul University, Graduate School of Sciences, Istanbul.

Kevseroglu, K. (1999). Plant ecology. Ondokuz Mayıs University Faculty of Agriculture publications, No: 31, Samsun.

Kinay, A., \& Yilmaz, G. (2016). Effects of heterosis on agronomically important traits of oriental tobacco (Nicotiana tabacum L.) hybrids. Suleyman Demirel University Journal of the Faculty of Agriculture, 11(1), 89-94.

Kinay, A. (2014). Yield and quality properties in some oriental tobacco (Nicotiana tabacum L.) hybrids. Phd Thesis, Gaziosmanpasa University, Graduate School of Sciences, Tokat.

Korubin-Aleksoska, A. (2003). Investigation of environmental and genetic variability fors talk height and number of leaves pers talk in some tobacco cultivars and their F1 hybrids. Coresta Meeting Agro-Phyto Groups, Bucharest, Romania.

Korubin-Aleksoska, A., Miceska, G., \& Aleksoski, J. (2014). Plant breeding for creation of late-maturing oriental tobacco genotypes. Tymyн/Tobacco, 64(1-6), 5-11.

Kurt, D. (2019). Genotype x Environment interactions of Basma type tobacco (Nicotiana tabacum L.) lines selescted for superior characterstics. Phd Thesis, Gaziosmanpasa University, Graduate School of Sciences, Tokat.

Kurt, D., \& Ayan, A. K. (2014). Effect of the different organic fertilizer sources and doses on yield in organic tobacco (Nicotiana tabacum L.) production. Journal of Agricultural Faculty of Gaziosmanpasa University, 31(2), 7-14.

Lambers, H., Chapin, S. F., \& Pons, L. P. (2000). Plant physiological ecology. Springer-Verlag, New York.

Ozcan, H. (2014). Effects of different harvest methods on yield and quality of tobacco (Nicotiana tabacum L). MSc Thesis, Gaziosmanpasa University, Graduate School of Sciences, Tokat.

Peksuslu, A. (1998). The morphological phsiological and biochemical characteristics of some Turkish tobacco varieties in IzmirBornova conditions. Phd Thesis, Ege University, Graduate School of Sciences, Izmir.

Peksuslu, A., Yilmaz, I., Inal, A., \& Kartal, H. (2012). Turkey tobacco genotypes. Journal of Aegean Agricultural Research Institute, Anadolu, 22(2), 82-90.

Ryu, M. H., Choi, S. I., \& Lee, C. H. (1989). The relation of environmental factors to the quality and chemical constituents of oriental tobaccos: III; Quality and physical properties as affected by light intensity and temperature. Korean Journal Crop Science, 34(1), 40-47.

Sadeghi, S. M., Samizadeh, H., Amiri, E., \& Ashouri, M. (2011). Additive main effects and multiplicative interactions (ammi) analysis of dry leaf yield in tobacco hybrids across environments. African Journal of Biotechnology, 10(21), $4358-4364$.

Sekin, S. (1986). Tobacco quality and difficults in measuring it. Turkey Tobaccos and Future Symposium, Tokat Governorship, Tokat.

Sencar, O., \& Gokmen, S. (2004). Agricultural Ecology. Gaziosmanpasa University faculty of Agriulture publications, No:8, Tokat.

Silim, S. N., Saxena, M. C., \& Erksine, W. (1993). Adaptation of lentil to the mediteranean environment: II. Response to moisture supply. Experimental Agriculture, 29, 21-28.

Smith, A. M., Zeeman, S. C., Thorneycroft, D., \& Smith, S. M. (2004). Starch mobilization in leaves. Journal of Experimental Botany, 54(382), 577-583. 
Senbayram, M., Ekren, S., \& Sekin, S. (2005). Effects of ecological condidtions and nutrients on oriental tobacco quality. Workshop on Tobacco Farming and Problems in the Aegean Region, Ege University, Izmir.

TADB. (2019). Activity Reports of 2014-2015-2016 Years. Republic of turkey Ministry of Agriculture and Forestry, Department of Tobacco and Alcohol, Ankara.

Tomov, N. (1990). Variability and stability on some indicators in the plants by oriental type tobacco. Plant-growing Science, $27(2), 35-41$.

Usturali, A., Apti, R., Otan, R., Yazan, G., \& Sengul, H. (1998). Selection studies on Sarıbağlar subpopulation in the Aegean tobacco region. Journal of Aegean Agricultural Research Institute, Anadolu, 8(1), 1-15.

Yilmaz, G., \& Kinay, A. (2011). Effects of different nitrogen rates on yield and quality of tobacco (Nicotiana tabacum L.). Turkey IX. Field Crops Congress, Uludag University, Bursa.

Zorba, T. (2008). A study on determination of tobacco cultivars and lines, best suited for Black Sea region and their expertise data. MSc Thesis, Ondokuz Mayıs University, Graduate School of Sciences, Samsun. 